\title{
Relationships between Knowledge, Attitudes and Interests of Spanish Pre- university Students in Relation to Different Areas of Biotechnology
}

\author{
Luisa López-Banet ${ }^{1 *}$, Cristina Ruiz González ${ }^{1}$, Enrique Ayuso Fernández ${ }^{1}$ \\ 1 University of Murcia, SPAIN
}

Received 14 June 2020 - Accepted 6 October 2020

\begin{abstract}
Biotechnology presence both in curricula and among researches regarding its teaching and learning processes is constantly increasing. The knowledge, attitudes and interests of 184 Spanish pre-university students on biotechnology in the fields of health, food, industry and environment have been analyzed in this work. The results showed that while some areas are well known, favourable attitudes and interests depend on other factors. Thus, positive correlations have been found between: (1) knowledge and interest towards almost all areas considered (rs .152-.214) except for fermentation, (2) knowledge and attitude regarding the use of fermentation for food production (rs .325) and applications related to improve the environment (rs .239), (3) and attitude and interest only in the medical field ( $r s .327$ ). As a conclusion, it is important to consider the relationships between these three constructs for designing activities including socio-scientific issue in order to facilitate the analysis of information in a critical way.
\end{abstract}

Keywords: attitudes, biotechnology, interests, knowledge, Secondary Education, socio-scientific issue

\section{INTRODUCTION}

Biotechnology is an area undergoing constant growth that generates valuable knowledge. Since it is immersed in some socio-scientific issues, students of this subject are motivated not only to understand its biological principles, but also to be aware of the possible benefits and risks (political, social, legal and ethical in nature) that derive from its development (Hammann, 2018). Therefore, citizens must have a critical opinion regarding the use of biotechnology. In the following sections, there is a global vision of the knowledge, attitudes and interests of students of different educational levels, highlighting the studies that have been carried out in Spain.

\section{The Aspects of Biotechnology Studied in Secondary Education in Spain}

The use of living organisms to promote development in the areas of industry, medicine and agriculture for the benefit of humankind is known by the term of Biotechnology. From vaccines, diagnosis, identifying and combatting diseases, the protection and preservation of biodiversity, to polluted air decontamination, as well as increased crop and food production, biotechnology aim is to improve the quality of life for all (UNESCO, 2017). As in other educational systems, the first school contents on biotechnology in Spain are introduced in the last secondary course (15-16 years), in the 4th year of Compulsory Secondary Education, basic contents are introduced within the optional subjects of Biology and Geology, especially those related to the fields of health and nutrition.

Although, it is not until the Baccalaureate, with ages between 16 and 18 years, and for those students who specialise in the science curriculum, that it is learnt in a more detailed way. In Spain, the Baccalaureate is a voluntary stage after secondary education, and prior to higher education. The Baccalaureate degree allows students to enrol in a Higher Degree Formative Cycle of Vocational Training or, if they pass an entrance exam, in a University. Specifically, aspects related to biotechnology appear in four of the five content blocks of the 2nd year of the Baccalaureate (2B hereafter) in the subject of Biology, from the molecular, cellular and microbiological perspectives, as it is included in the 


\section{Contribution to the literature}

- The importance of biotechnology is increasing due to its new applications in the fields of health, food (GMOs), the environment and industry.

- Students are more favourable to the use of biotechnology for improve human health. The attitudes will depend not only on the purpose of each biotechnological application but also on the organism involved.

- Interests in knowing about biotechnology and favourable attitudes to the use of its applications is correlated to a greater knowledge of basic aspects of biotechnology.

curriculum RD 1105/2014 (Ministry of Education, Culture and Sports, 2015). In the general framework of the review, we have included works on knowledge, attitudes and interests in Spain, but those are not very common in our environment and at different educational levels from secondary. Because of that, we have included some international works about biotechnology education in the review and we consider that our study is important as previous step to the elaboration of didactic proposals.

\section{What are the Knowledge, Attitudes and Interests' Gaps Owned by Students in the Field of Biotechnology in Spain?}

The few studies on biotechnology and education in Spain have focused on future primary school teachers (a stage in which biotechnology is not studied) and the last year of Spanish secondary education (15-16 years). Next, we are going to show some of the results that serve to summarize to the reader what is the situation of knowledge and attitudes of students in our country at the mentioned levels.

Starting from a higher academic level, Casanoves et al. (2015) state that Spanish preservice teachers understand the importance of the usefulness of biotechnology, although they show deficient knowledge in basic aspects, for instance DNA structure or treatment of genetic information. According to these authors, future teachers are against the acquisition of products that involve genetic modification of organisms (GMOs). Nevertheless, they support the use of biotechnology in medicine and they are interested in learning scientific advances in biotechnology.

Sáez et al. (2008) have identified that Spanish secondary students value the utility of biotechnology, although they make moral assessment to approve its uses. Thus, using living beings would be accepted depending on the affinity with humans. Moreover, students prefer products that are more natural, a fact that affects the field of transgenic. On the other hand, "maximizing health justifies any technological intervention", so an improvement in health is sufficient justification to support biotechnology for biomedical purposes, as well as for environmental reasons. Besides, students express a great confidence in science and technology to solve any problem, above all the medical or environmental ones, considering the "principle of the technological solution".

Students in the last year of Compulsory Secondary Education present enough deficiencies in basic concepts, thus they do not link the traditional biotechnology processes with the term biotechnology. This indicates that they may not know the procedures through which foods such as bread or cheese are produced, and possibly ignore that microorganisms participate in this process. However, students have a good knowledge of concepts more related to modern biotechnology (De la Vega et al., 2018). Students increase their disagreement with the use of biotechnology as there is an increase in complexity of the organisms used in these processes. In this way, they strongly agree on the use of microorganisms, but this decreases when we speak of plants and animals, and falls when we refer to human beings. Only when the use of biotechnology in humans is referred to improvements in medicine, do students agree somewhat (De la Vega et al., 2018).

As regards Spanish pre-university students to different areas of biotechnology, Ruiz et al. (2021) assessed the knowledge and values towards biotechnology and, specifically, about biopharmacology. They found that the students are more favourable towards the use of biotechnology aimed at solving health problems, or those that do not require animals in research. Moreover, attitudes towards different applications of biotechnology in this study show, like other works, that not all biotechnological fields had the same acceptance. Therefore, it is necessary to address them separately and review the students' justifications. Thus, the students had a favourable attitude to the use of traditional fermentation, but not so much in cases involving the manipulation of genes. What is more, if this manipulation could increase the nutritional value of the food, the students would accept it more than if the genetic manipulation were performed to obtain better commercial characteristics.

In the field of health, the study results suggest that the students positively assessed preventive molecular diagnosis and gene therapy while the acceptance of genetic modification of animals for the study of human diseases was much lower or it was openly rejected, coinciding with the conclusions of other works Sáez et al. (2008). The use of biotechnology in industry for the production of drugs is an application that was accepted 
quite well by the students and they did not reject it (for example, its use for the production of neither cosmetics nor plastics). However, they did not especially value it, considering that there is little justification for scientific research in this area.

\section{Students' Knowledge, Attitudes and Interests in Other Educational Contexts}

The students' knowledge of biotechnology is generally defined as a rational knowledge, of probationary content, about key concepts and procedures in this area (Fonseca et al., 2012). Nevertheless, it has been consistently described as insufficient and erroneous by different authors high school students aged 12 to 17 (Dawson, 2007), university students from 18 to 25 years of age (Prokop et al., 2007), high school and university students from 14 to 27 years old (Usak et al., 2009), high school students aged between 15 and 17 at the beginning of the Baccalaureate (Ruiz et al., 2017a) and high school students from 17 to 18 years old (Chen et al., 2016). Hammann (2018) also stated that, although more recent studies show a certain improvement in students' knowledge, research clearly shows a lack of meaningful knowledge.

In many studies, basic errors have been found, such as a lack of knowledge of key points of genetics; for instance, regarding DNA itself and its transmission. "Common tomatoes do not contain genes, while genetically modified tomatoes do" is a sentence that is usually presented in studies on biotechnology (AbuQamar et al., 2015; Gaskell et al., 2006). Another common misconception is not to locate the complete genetic information in each of the cells of the organism (Ruiz et al., 2017b).

Considering the important role of bacteria in numerous research works in biotechnology, studies on students' knowledge of microorganisms are also of interest. So, Harms (2002) inquired about the deficient knowledge of their role in different parts of the human body and found that, for example, a digestive function (absorbing 'noxious agents' or processing unwanted substances in the liver), purification of the blood or increasing the effectiveness of bile were attributed to them. Moreover, in the work of Simonneaux (2000) students emphasised that bacteria feed on waste matter and that the intestinal flora is composed of 'good bacteria' that digest fibre. Harms (2002) found that students could cite foods that are prepared with the use of bacteria, such as yogurt, but also mentioned foods that are prepared without them such as wine or beer; in addition, the first biotechnological process that students related to bacteria was the purification of water, by decomposition of chemicals. Finally, Simonneaux (2000) also noted that the industrial use of bacteria is practically unknown to students since bacteria are often seen as decomposition agents, so students can hardly conceive their use in the manufacture of food.
However, in terms of knowledge about biotechnology, we find that students in health related fields know the use of GMOs (Öztürk-Akar, 2016) and they have knowledge of the production of medicines and vaccines by biotechnology (Fonseca et al., 2012). Regarding food, few students describe genetically modified foods well (Dawson, 2007). Prokop et al. (2007) found that some students had the idea that genetically modified foods can contain dangerous chemicals. Occelli et al. (2011) indicated that students consider that tomato, soy, corn and other processed or packed products are related to genetically modified foods. Finally, in the field of agriculture, livestock and the environment, students know that genetic modification of animals and plants can increase their productivity and resistance to diseases (Öztürk-Akar, 2016), but few students know about the elimination of contaminating oils using genetically modified bacteria (Fonseca et al., 2012).

Students have very positive attitudes towards studying the field of biotechnology (Kidman, 2009). However, the study of attitudes towards scientific subjects is quite complex since these multidimensional constructs are determined by knowledge, beliefs or ideas on the subject in question (cognitive component); the feeling that they produce between acceptance and rejection (affective component); and how they motivate us to carry out actions (behavioural component) (Reid, 2006). Authors like Klop and Severiens (2007) and Fonseca et al. (2012) agree on the appropriateness of this multidimensional approach to understand the attitudes towards biotechnology. Moreover, biotechnology education differs from most other topics or subjects in the natural sciences as ethical, emotional, political, and social aspects are often integrated parts (Nordqvist \& Johansson, 2020). Nevertheless, in many students, this knowledge seems to be superficial, especially in the domain of the terminology and in the ability to discriminate current uses of hypothetical and future possibilities. In addition, a proportion of students showed little understanding of this topic, and probably for this reason the justifications of the students for their ethical points of view, as well as their responses written in questionnaires, showed very little ability to justify their decisions (Lieshout \& Dawson, 2016).

However, in relation to the medical field, most of the studies suggest that students are in favour of the use of genetic engineering for research (Chen et al., 2016), the use of GMOs in medicine (Öztürk-Akar, 2016), the production of new medicines and the diagnosis and/or treatment of diseases (Occelli et al., 2011) and gene therapy and classical applications (Fonseca et al., 2012). However, in other cases, the use of techniques such as gene therapy does not have such acceptance in general (Gardner \& Troelstrup, 2015).

In the field of food and in terms of attitudes towards the consumption of genetically modified foods, many students do not feel safe buying these products (Öztürk- 
Akar, 2016). Some consider that they contain chemical substances capable of harming the human body and thus can involve health risks (Usak et al., 2009). Most of the adolescents interviewed by Jurkiewicz et al. (2014) found more negative aspects than positive ones regarding genetically modified foods.

According to Chen et al. (2016), students are opposed to the applications of biotechnology in the agricultural, livestock and environmental fields, showing some concern for the negative impact on the environment. However, students have more positive attitudes towards the elimination of diseases in plants or wastewater treatment (Öztürk-Akar, 2016), and towards applications such as plant improvement or livestock production (Occelli et al., 2011). The students examined by Jurkiewicz et al. (2014) approached the achievements of biotechnology around genetic modification of plants and animals in a relatively sceptical way. The acceptance by students of research in genetic technology for environmental sustainability is also very high, but they show some concern regarding the regulation of risks in the environment associated with biotechnology (Gardner \& Troelstrup, 2015).

The interest and the importance that are given to something are related to the motivation, both intrinsic and extrinsic, provided by that topic and are determining factors for both learning and behaviour (Ryan \& Deci, 2000). In this way, understanding how these two dimensions interact with each other and with knowledge and attitudes provides a baseline for the design of better educational strategies (Fonseca et al., 2012). Harms (2002) reported that interest in biotechnology has little basis in knowledge, being more a kind of curiosity and a general openness towards a new technology. Also, the interest in genetic engineering develops parallel to the interest in other general social issues. On the other hand, Prokop et al. (2007) indicated that many students are interested in knowing more about GMOs. Fonseca et al. (2012) reported that students who do not study science are the ones least interested in biotechnology, followed by those who do but have not chosen Biology, the most interested students being the ones who take this course. However, all of them recognise its importance to the improvement of the quality of life. Kidman (2010) indicated that students feel that bioethics, prenatal testing and human cloning should be included in the lessons of Biology courses and, in addition, paternity tests for human uses based on biotechnology were what generated most interest in students. On the other hand, they were uninterested in the study of key ideas related to agricultural biotechnology. Students do show an interest in the advantages and disadvantages of genetic technology, or in its risks, in the possibilities of application in medical care, in the maintenance of global nutrition or in ethical issues, and they show even less interest in the application of genetic technology in animal and plant production (Harms, 2002).

\section{Relationships between Knowledge, Attitudes and Interests with Respect to Biotechnology}

There is a certain consensus in research into the origin of attitudes, which are predispositions to act in a certain way based on responses of an affective, cognitive or behavioural nature. Since these three elements are interrelated, as we have indicated previously, they configure the attitude, so, to initiate a change in them, we must intervene in these three dimensions (Arnau \& Montané, 2010). Moreover, if we consider, as many studies have pointed out (for example, Vázquez \& Manassero, 2007), the leading role of feelings and emotions over cognitions (learning) and behaviours (decision making), and the former govern learning and behaviours, they might be adequately addressed in the school setting.

However, the work that has attempted to find correlations between the knowledge of biotechnology and the attitudes towards its applications shows a lot of controversy. Undoubtedly, one factor to consider, in this respect, is that the results of the various investigations depend on factors such as the construction of the sample, the methods of data collection and the way in which understanding is determined (Dawson, 2007). In this way, we find investigations like those of Prokop et al. (2007), which point to a positive correlation between attitudes and the interests that students attach to biotechnology. Other authors say that better knowledge of biotechnology is not always necessarily reflected in greater acceptance of its applications (Klop \& Severiens, 2007; Öztürk-Akar, 2016). The complexity of these relationships is shown by the fact that there can be a positive relationship between having more knowledge and a favourable attitude towards biotechnology among students who are either more supportive of or opposed to research in this field. However, there is no such correlation between groups of students who have intermediate positions on biotechnological applications; thus, other aspects of attitudes patterns such as affective evaluation and behavioural intentions are implied (Klop \& Severiens, 2007). This uncertain knowledge-attitudes relationship may be due to what has already been said about the complexity of attitudinal responses (Fonseca et al., 2012).

\section{Purpose of this Work}

In our study, we sought to understand the conceptions, attitudes and interests of the students in different fields of biotechnology. As previously noted in the theoretical framework, science students in their last academic year of high school, who had chosen Biology as an optional subject, were expected to have a high interest in biotechnology; moreover, we have not found 


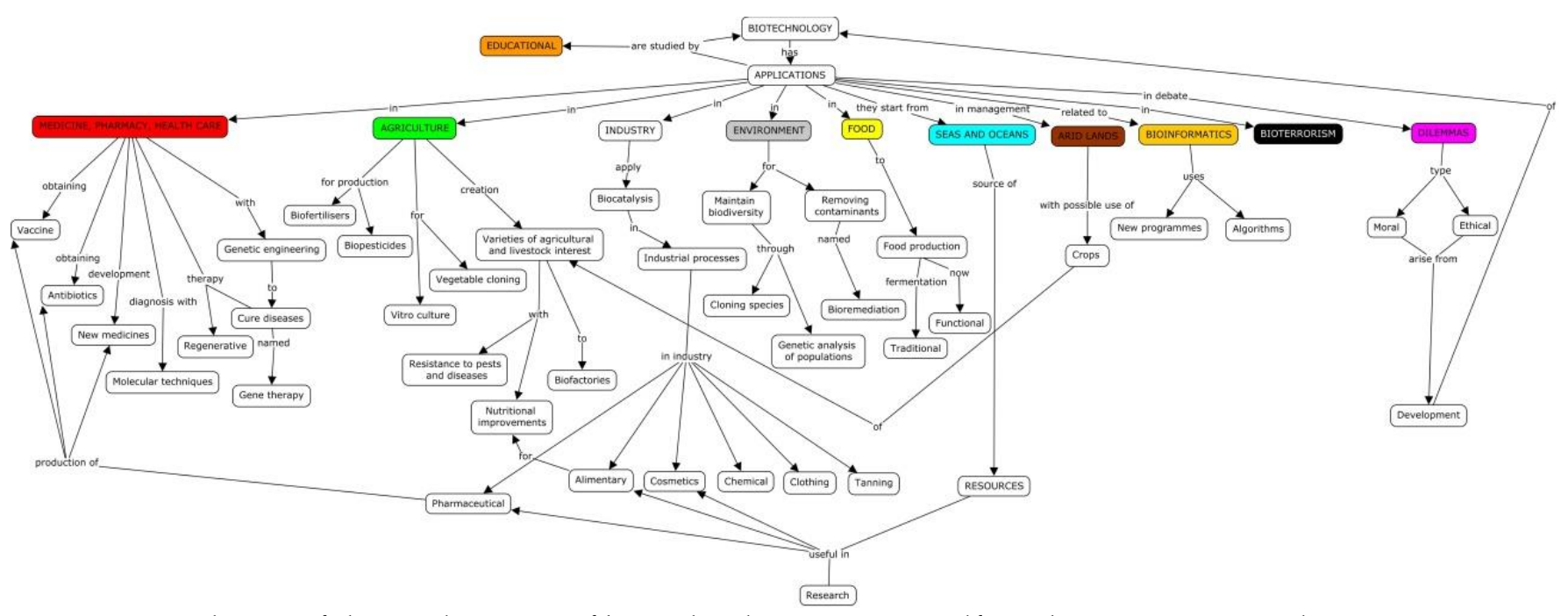

Figure 1. Mind map of the applications of biotechnology. Source: self-made using Cmaptools

a lot of studies in this academic level in Spain. Therefore, in addition to analysing knowledge, attitudes and interests separately, we wanted to study how these three constructs interact with each other, in the currently most important fields of biotechnology: health, food, industry and environment. The study tries to explain the applicability of the findings in the field of biotechnology didactics a part of a wider project which aim is to propose useful teaching activities as a reference for teachers of Baccalaureate. Particularly, in this work the research question is:

Is there any correlation among knowledge, attitudes and interests of last secondary education level (preuniversity) Spanish students related to biotechnology in different fields?

\section{Methodology}

a) Characteristics of the sample: 184 high school students from 6 schools located in the southeast of Spain in different size cities (3 medium cities, 2 small cities and 1 sited in a rural environment) participated in the present study. The schools were randomly selected in each city and all $2^{\circ}$ Baccalaureate science students (17-18 years old) were evaluated, being the last year of secondary education in Spain.

b) Design of instruments to collect information: The classification of the specialties in biotechnology by colours, proposed by several authors (Castro et al., 2017, Da Silva, 2004; Díaz, 2010; Kafarski, 2012), has been used and a mind map which reflects the main areas of application is presented (Figure 1). Based on this, as well as the curricular orientations, and the analysed antecedents, especially in those where the knowledge, attitudes and interests of the students regarding biotechnology were studied, a mind map which reflects the main areas was elaborated; this represents the starting point for the present research approach. Based on this scheme, an initial questionnaire was designed, which also considered the influence of the articles that have been previously discussed, and it was focused and differentiated in terms of knowledge, attitudes and interests regarding biotechnology in the medical, food, industrial and environmental fields.

This questionnaire was tested in a pilot study through individual interviews with 12 students from different centres and of differing academic performance. The results suggested the need to remove some questions that were too complex (the initial questionnaire included questions about laboratory techniques that were finally eliminated because they were not answered by the students), to modify the language and the structure of others and to adjust the time allowed for completion of the questionnaire to 3035 minutes.

The questionnaire consist of three sections: the first part was focused both on declaring the self-perception of knowledge regarding several biotechnological terms (I have never heard it, I have heard it but I do not know what it means or I have heard it and I know what it means) and also on providing a definition; the second part was dedicated to attitudes, using a Likert-type scale with values from 1 to 5 , with 1 being low levels for this construct and 5 corresponding to high levels; and the third one aim to determine interests toward biotechnology by means of a Likert-type scale similar to the second part. Nevertheless, along the results and discussion in this work, the items of the same category (medicine, food, industry and environment) will be described together in order to perform the corresponding correlations between the three constructs (knowledge, attitudes, and interests) by fields of biotechnology. The data was collected from May to June 2017. The questionnaire was administered during class periods, without time restrictions, under the supervision of the teacher and the researcher.

c) Analysis of the results: The Statistical Package for the Social Sciences (SPSS) version 20.0 was used to code the collected data. Based both on self-perception of 
Table 1. Degree of knowledge, attitudes and interests in applications of biotechnology in medicine (frequencies, mean values and standard deviation)

\begin{tabular}{|c|c|c|c|c|c|c|c|}
\hline & \multicolumn{7}{|c|}{ Degree of knowledge* } \\
\hline & 1 & 2 & 3 & 4 & 5 & Mean & SD \\
\hline Preventive molecular diagnosis & 59 & 54 & 5 & 27 & 36 & 2.6 & 1.55 \\
\hline \multirow[t]{3}{*}{ Gene therapy } & 48 & 43 & 10 & 24 & 56 & 3.0 & 1.64 \\
\hline & \multicolumn{7}{|c|}{ Attitudes** } \\
\hline & 1 & 2 & 3 & 4 & 5 & Mean & SD \\
\hline $\begin{array}{l}\text { Preventive molecular diagnosis: to see the diseases to which a } \\
\text { person may be susceptible in the future }\end{array}$ & 6 & 6 & 19 & 35 & 113 & 4.4 & 1.03 \\
\hline $\begin{array}{l}\text { Gene therapy: alteration of genes in human tissue cells to treat } \\
\text { diseases }\end{array}$ & 5 & 5 & 31 & 58 & 81 & 4.1 & .98 \\
\hline Genetically modify animals to study human diseases & 34 & 41 & 51 & 32 & 25 & 2.9 & 1.29 \\
\hline \multirow{3}{*}{$\begin{array}{l}\text { Use of drugs, vaccines and hormones obtained through genetic } \\
\text { engineering processes }\end{array}$} & 3 & 1 & 9 & 33 & 133 & 4.6 & .76 \\
\hline & \multicolumn{7}{|c|}{ Interests $* * *$} \\
\hline & 1 & 2 & 3 & 4 & 5 & Mean & SD \\
\hline $\begin{array}{l}\text { I find it interesting to know about different applications and } \\
\text { implications of biotechnology in Health }\end{array}$ & 3 & 3 & 10 & 30 & 135 & 4.6 & .81 \\
\hline
\end{tabular}

knowledge and on the given definitions, the different authors of the study classified from 1 to 5 each student's knowledge of biotechnological terms in order to calculate correlations between the three constructs (attitudes and interests presented Likert scale). The analysis performed was descriptive (frequencies, mean values and standard deviation) and the correlation between the variables was evaluated using the Spearman's rank correlation coefficient. To calculate the correlations, the mean values of knowledge, attitudes and interests of each student were taken into account.

Reliability of the results was also analyzed using the Cronbach's alpha coefficient which was .721 in the questions about knowledge of applications, .747 related to attitudes and .814 on interests, so it indicates an acceptable reliability range.

\section{RESULTS AND DISCUSSION}

In order to study the responses of the participants, we have taken into account that, as it has been previously indicated in other works, not all biotechnological applications have the same acceptance. Therefore, it is necessary to split them in biotechnology fields, as health, food production, industry and environment.

\section{Relationships between Knowledge, Attitudes and Interests with Respect to Using Biotechnology in Medicine}

In medical fields (Table 1), we have found that the knowledge of biotechnology is adequate but not so good contrary to Öztürk-Akar (2016) and Fonseca et al. (2012) described. In fact, among the applications presented in the questionnaire, gene therapy (3.0) and preventive molecular diagnosis (2.6) were described less frequently and worse than others from different fields by the students who completed the questionnaire. On the other hand, we have found that gene therapy is better described than preventive molecular diagnosis.

Regarding attitudes, the study results suggest that the students positively assessed preventive molecular diagnosis (4.4), gene therapy (4.1) and the use of biotechnology in industry for the production of drugs (4.6) while the acceptance of genetic modification of animals for the study of human diseases was much lower or it was openly rejected (2.9), coinciding with the conclusions of other works Sáez et al. (2008). We highlight in our study that this will depend not only on the purpose of each biotechnological application but also on the organism involved, the attitudes in relation to medicine being more favourable (Fonseca et al., 2012; Occelli et al., 2011; Öztürk-Akar, 2016; Sáez et al., 2008). There was no justification expressed to use animal research for medical purposes and, contrary to what Gardner and Troelstrup (2015) found, the students accepted gene therapy. However, they declared a high interest in knowing the techniques and applications of biotechnology in health (4.6).

The results of the analysis of correlations using Spearman's rho (rs) between these three constructs related to biotechnology in health are shown (Table 2).

Students' knowledge with respect to the use of biotechnology in health was positively correlated with their interests globally in this field ( $\mathrm{rs}=.214, \mathrm{n}=177, \mathrm{p}<$ .01). Interests were also positively correlated with attitudes towards applications in the field of health ( $\mathrm{rs}=$ $.327, \mathrm{n}=171, \mathrm{p}<.001)$. 
Table 2. Correlation between constructs: knowledge, attitudes and interests regarding biotechnology in medicine

\begin{tabular}{lccc}
\hline Correlation & $\begin{array}{c}\text { Applications in medicine } \\
\text { Knowledge }\end{array}$ & $\begin{array}{c}\text { Applications in medicine } \\
\text { Attitudes }\end{array}$ & $\begin{array}{c}\text { Applications in medicine } \\
\text { Interests }\end{array}$ \\
\hline Applications in medicine Knowledge & 1 & .016 & $\mathbf{. 2 1 4 ^ { * * }}$ \\
\hline Applications in medicine Attitudes & .016 & 1 &. $\mathbf{3 2 7 ^ { * * * }}$ \\
\hline Applications in medicine Interests &. $\mathbf{2 1 4 ^ { * * }}$ &. $\mathbf{3 2 7 ^ { * * * }}$ & 1 \\
\hline $\begin{array}{l}\text { Values are Spearman's rank correlation coefficients, }{ }^{* *} \text { the correlation is significant at the } .01 \text { level (bilateral), } \\
\text { significant at the } .001 \text { level (bilateral). }\end{array}$ & &
\end{tabular}

Table 3. Degree of knowledge, attitudes and interests in fermentation and transgenic foods (frequencies, mean values and standard deviation)

\begin{tabular}{|c|c|c|c|c|c|c|c|}
\hline & \multicolumn{7}{|c|}{ Degree of knowledge* } \\
\hline & 1 & 2 & 3 & 4 & 5 & Mean & SD \\
\hline \multirow[t]{3}{*}{ Fermentation for food production } & 14 & 66 & 31 & 12 & 57 & 3.2 & 1.41 \\
\hline & \multicolumn{7}{|c|}{ Attitudes** } \\
\hline & 1 & 2 & 3 & 4 & 5 & Mean & SD \\
\hline Fermentation: use of bacteria and yeasts in the production of & 4 & 4 & 21 & 43 & 111 & 4.4 & .93 \\
\hline
\end{tabular}

yogurt, bread.

\begin{tabular}{|c|c|c|c|c|c|c|c|}
\hline & \multicolumn{7}{|c|}{ Degree of knowledge* } \\
\hline & 1 & 2 & 3 & 4 & 5 & Mean & SD \\
\hline \multirow{3}{*}{ Transgenic foods } & 7 & 30 & 40 & 6 & 98 & 3.9 & 1.33 \\
\hline & \multicolumn{7}{|c|}{ Attitudes** } \\
\hline & 1 & 2 & 3 & 4 & 5 & Mean & SD \\
\hline Modify yeast to obtain a better taste for bread & 19 & 27 & 58 & 41 & 37 & 3.3 & 1.24 \\
\hline $\begin{array}{l}\text { Modify animals to obtain food in greater quantity or with } \\
\text { modified characteristics (meat, milk) }\end{array}$ & 56 & 40 & 44 & 22 & 17 & 2.5 & 1.30 \\
\hline $\begin{array}{l}\text { Nutritional objective: production of genetically modified plant } \\
\text { varieties, such as golden rice }\end{array}$ & 9 & 28 & 49 & 45 & 50 & 3.6 & 1.19 \\
\hline \multirow[t]{3}{*}{$\begin{array}{l}\text { Commercial objective: to grow genetically modified vegetables } \\
\text { with better appearance, late ripening, etc. }\end{array}$} & 49 & 35 & 46 & 25 & 28 & 2.7 & 1.40 \\
\hline & \multicolumn{7}{|c|}{ Interests ${ }^{* * *}$} \\
\hline & 1 & 2 & 3 & 4 & 5 & Mean & SD \\
\hline I find it interesting to know about different applications and & 10 & 9 & 28 & 47 & 86 & 4.1 & 1.16 \\
\hline
\end{tabular}

implications of biotechnology in Food

Notes: *From less to greater knowledge, being 1 students who say they do not know the application and do not give examples and 5, students who say they know it and give various examples; **Being 1 totally disagree and 5 totally agree; ***Being 1 not interested and 5 totally interested

\section{Relationships between Knowledge, Attitudes and Interests with Respect to Using Biotechnology to Fermentation Processes and to Produce Transgenic Foods}

The applications related to fermentation processes (3.2) and transgenic foods (3.9) were recognised and properly described by the students surveyed (Table 3). Moreover, although students described transgenic foods well, as Dawson (2007) also mentioned, they doubted whether they could pose a danger too (Prokop et al., 2007). In accordance with Öztürk-Akar (2016), our students knew that the genetic modification of plants and animals can improve their productivity.

In the food sector, the students accepted traditional techniques, such as fermentation (4.4), more than genetic modification of food, which they preferred to be for nutritional (3.6) rather than commercial purposes (2.7) or animals that produce a greater quantity of food or food with modified characteristics (2.5). In addition, we agree with Öztürk-Akar (2016), Usak et al. (2009) and Jurkiewicz et al. (2014) in having found that our students were reluctant to accept the use of transgenic for food production, in particular if the objective is not nutritional. At the same time, our students declared a high interest in knowing about the techniques and applications of biotechnology in the field of food (4.1), in general.

In order to study the relationships between knowledge, attitudes and interests with respect to the use of fermentation to produce food and transgenic foods, we have differentiated them as it is shown in Tables $4 \mathrm{a}$ and $4 \mathrm{~b}$, respectively.

The analysis of the results obtained among our students, we consider that it is interesting to note that while in the field of fermentation student's knowledge was positively correlated with attitudes $(\mathrm{rs}=.325, \mathrm{n}=$ $179, \mathrm{p}<.001)$, in the field of transgenic foods, we found students' knowledge was positively correlated with their interests globally ( $\mathrm{rs}=.152, \mathrm{n}=177, \mathrm{p}<.05)$, but not between knowledge and attitude. Probably, socioscientific controversies about the risk of the use of transgenic foods in Spain determine that, despite having 
Table 4. Correlation between constructs: knowledge, attitudes and interests regarding biotechnology in fermentation and transgenic foods

\begin{tabular}{|c|c|c|c|}
\hline Correlation (a) & $\begin{array}{l}\text { Applications in } \\
\text { fermentation } \\
\text { Knowledge }\end{array}$ & $\begin{array}{l}\text { Applications in } \\
\text { fermentation } \\
\text { Attitudes }\end{array}$ & $\begin{array}{l}\text { Applications in } \\
\text { fermentation } \\
\text { Interests }\end{array}$ \\
\hline Applications in fermentation Knowledge & 1 & $.325^{* * *}$ & .139 \\
\hline Applications in fermentation Attitudes & $.325^{* * *}$ & 1 & .014 \\
\hline Applications in fermentation Interests & .139 & .014 & 1 \\
\hline Correlation (b) & $\begin{array}{l}\text { Applications in transgenic } \\
\text { foods Knowledge }\end{array}$ & $\begin{array}{l}\text { Applications in transgenic } \\
\text { foods Attitudes }\end{array}$ & $\begin{array}{l}\text { Applications in transgenic } \\
\text { foods Interests }\end{array}$ \\
\hline Applications in transgenic foods Knowledge & 1 & .106 & $.152^{*}$ \\
\hline Applications in transgenic foods Attitudes & .106 & 1 & .089 \\
\hline Applications in transgenic foods Interests & $.152 *$ & .089 & 1 \\
\hline
\end{tabular}

Table 5. Degree of knowledge, attitudes and interests in applications of biotechnology in industry (frequencies, mean values and standard deviation)

\begin{tabular}{|c|c|c|c|c|c|c|c|}
\hline & \multicolumn{7}{|c|}{ Degree of knowledge* } \\
\hline & 1 & 2 & 3 & 4 & 5 & Mean & SD \\
\hline \multirow[t]{3}{*}{ Use of plants or bacteria in industry } & 28 & 68 & 29 & 15 & 36 & 2.8 & 1.38 \\
\hline & \multicolumn{7}{|c|}{ Attitudes** } \\
\hline & 1 & 2 & 3 & 4 & 5 & Mean & SD \\
\hline \multirow[t]{3}{*}{ Production of cosmetics, plastics or fuels using plants or bacteria } & 16 & 21 & 68 & 45 & 29 & 3.3 & 1.14 \\
\hline & \multicolumn{7}{|c|}{ Interests $* * *$} \\
\hline & 1 & 2 & 3 & 4 & 5 & Mean & SD \\
\hline I find it interesting to know about different applications and & 23 & 29 & 45 & 35 & 48 & 3.3 & 1.36 \\
\hline
\end{tabular}

implications of biotechnology in the industry

Notes: *From less to greater knowledge, being 1 students who say they do not know the application and do not give examples and 5, students who say they know it and give various examples; ${ }^{* *}$ Being 1 totally disagree and 5 totally agree; ***Being 1 not interested and 5 totally interested

Table 6. Correlation between constructs: knowledge, attitudes and interests regarding biotechnology in industry

\begin{tabular}{lccc}
\hline Correlation & $\begin{array}{c}\text { Applications in industry } \\
\text { Knowledge }\end{array}$ & $\begin{array}{c}\text { Applications in industry } \\
\text { Attitudes }\end{array}$ & $\begin{array}{c}\text { Applications in industry } \\
\text { Interests }\end{array}$ \\
\hline Applications in industry Knowledge & 1 & .097 & $\mathbf{. 1 6 0}^{*}$ \\
\hline Applications in industry Attitudes & .097 & 1 & -.018 \\
\hline Applications in industry Interests & $\mathbf{1 6 0}$ & -.018 & 1 \\
\hline Valo
\end{tabular}

Values are Spearman's rank correlation coefficients, *the correlation is significant at the .05 level (bilateral).

adequate knowledge of the technique, they do not support its uses as it was expected. Values as environment, scientific knowledge, economy, ethics or health may influence in their decisions (Ruiz et al., 2021). Above all, they are less favourable towards genetic modification of animals or just a commercial purposes rather than nutritional purposes.

\section{Relationships between Knowledge, Attitudes and Interests with Respect to Using Biotechnology in Industry}

The industrial field has been shown to be the least known (2.8). Thus, the use of biotechnology in industry for the production of cosmetics, plastics or fuels is accepted for our students. However, they did not especially value it (3.3), considering that there is little justification for scientific research in this area (Table 5). Consequently, they declared a medium interest (3.3) in knowing about the techniques and applications of biotechnology in the industry.

In our work, the analysis of bivariate correlations between these three constructs related to the use of biotechnology in industry was carried out, based on the responses obtained in the different items involved (Table $6)$.

It is found that, as in other fields studied, there is a positive correlation between student's knowledge about biotechnology applied to industry and interests in it (rs $=.160, \mathrm{n}=172, \mathrm{p}<.05)$.

\section{Relationships between Knowledge, Attitudes and Interests with Respect to Using Biotechnology for Environmental Purposes}

The applications that the students surveyed recognised and described best, among which they were presented, were those related to waste treatment by bioremediation (Table 7). In fact, unlike Fonseca et al. 
Table 7. Degree of knowledge, attitudes and interests in applications of biotechnology in environment (frequencies, mean values and standard deviation)

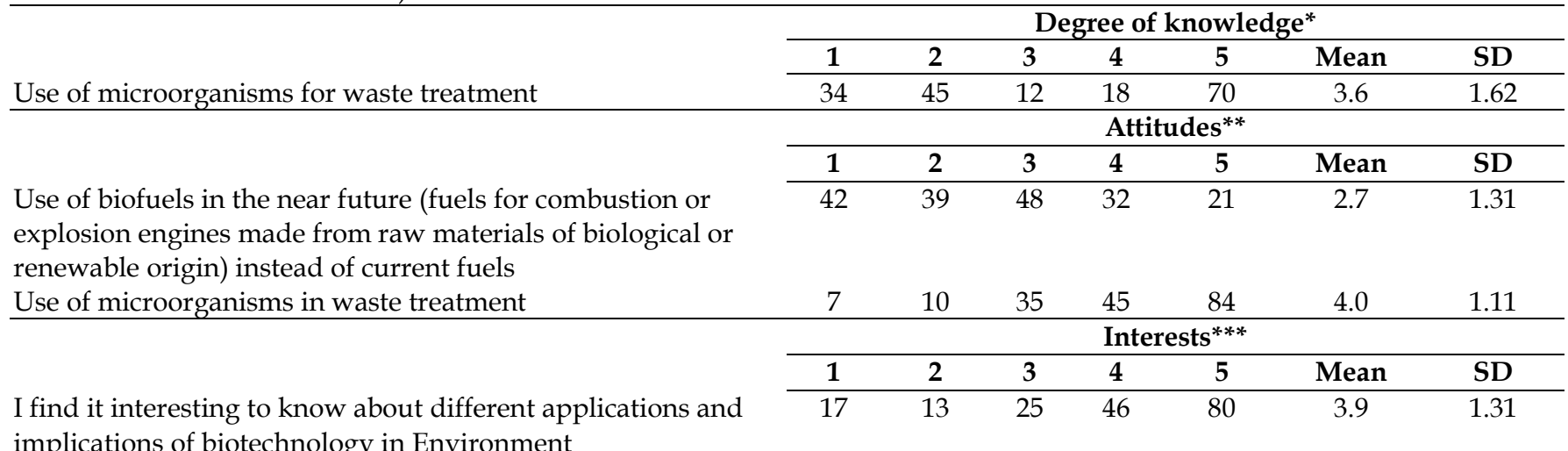

Notes: *From less to greater knowledge, being 1 students who say they do not know the application and do not give examples and 5, students who say they know it and give various examples; ${ }^{* *}$ Being 1 totally disagree and 5 totally agree; ${ }^{* * *}$ Being 1 not interested and 5 totally interested

Table 8. Correlation between constructs: knowledge, attitudes and interests regarding biotechnology in environment

Correlation Applications in Applications in $\quad$ Applications in

Environment Knowledge Environment Attitudes Environment Interests

\begin{tabular}{lccc}
\hline Applications in Environment Knowledge & 1 &. $\mathbf{2 3 9}$ & $\mathbf{. 1 9 0 ^ { * * * }}$ \\
\hline Applications in Environment Attitudes & $\mathbf{. 2 3 9 * *}$ & 1 & .021 \\
\hline Applications in Environment Interests &. $\mathbf{1 9 0}^{*}$ & .021 & 1 \\
\hline $\begin{array}{l}\text { Values are Spearman's rank correlation coefficients, } \\
\text { significant at the correlation is significant at the .05 level (bilateral), }\end{array}$ &
\end{tabular}

(2012), who indicated that few students knew about the bioremediation process, many of our students could identify and properly define it (3.6).

Regarding the biotechnological applications designed for the solution of environmental problems (4.0), as elimination of pollutants, our results were well disposed to the use of microorganisms for the treatment of waste through bioremediation, but they are not so optimistic about replacing current fuels with biofuels (2.7), in the future.

There were also favourable attitudes to the care of the environment, particularly for the treatment of pollutants, as in Öztürk-Akar (2016), rather than biofuels use. Besides, they declared certain interest (3.9) in knowing about the techniques and applications of biotechnology in this field.

The results of the analysis of the correlations between the knowledge, attitudes and interests related to biotechnology in environment in our work are shown in Table 8 .

Students' knowledge was positively correlated with their interests globally ( $\mathrm{rs}=.190, \mathrm{n}=176, \mathrm{p}<.05$ ) and it was also positively correlated with attitude ( $\mathrm{rs}=.239, \mathrm{n}$ $=176, \mathrm{p}=.001$ ).

\section{CONCLUSIONS AND EDUCATIONAL IMPLICATIONS}

The purpose of our study was to determine what knowledge, attitudes and interests are shown by some
Spanish students studying Biology in the $2^{\circ}$ school year of Baccalaureate (the last to enrol in a university scientific grade), since the scarce number of works about biotechnological education developed in our country. Moreover, none of them include the relationships between the three constructs at this academic level. Taking these data into account, the degree of knowledge acquired about basic concepts in biotechnology and its different applications (considering the educational level of the students) might be improved. Besides, conceptual errors that others pointed out have also been found (AbuQamar et al., 2015; de la Vega et al., 2018; Gaskell et al., 2006). Regarding the attitudes, they will depend not only on the purpose of each biotechnological field (the ones related to health are more favourable) but also on the organism involved. With respect to interests of students in the southeast of Spain who have chosen Biology, they consider it is useful to know about biotechnology and show curiosity about it, also especially in the field of health and food production.

The values of the correlation coefficients between knowledge, attitudes and interests obtained in our work indicate that they are dependent on the field of biotechnology that we study. Although the Spearman correlation coefficient gives us the degree of correlation, it should be considered, as stated at the beginning of the study (Dawson, 2007; Hammann, 2018), that the results of distinct investigations depend on factors such as the construction of the sample, the methods of data collection and the form in which understanding is determined, a fact that may complicate the comparison 
of different studies. In our work, we have found a positive correlation between students' knowledge and interests in most of the areas considered, such as biotechnology in health, transgenic food, industry or the environment. Moreover, positive correlations between student's knowledge and attitudes in the fields of fermentation for food production and the environment have been determined, and also between the attitudes and interests towards using biotechnology in medicine.

Thus, we agree with Prokop (2007) that there is a positive correlation, but also with Klop and Severiens (2007) and Öztürk-Akar (2006), who stated that greater knowledge of biotechnology does not always result in greater acceptance (we have analysed the correlation, but not the causality). Above all, we are with Fonseca et al. (2012) in pointing out how complex is it to determine the relationships between them because these are multidimensional constructs, determined by cognitive, affective and behavioural factors.

Having in mind all the information, individuals must be well prepared when making informed decisions about the applications of biotechnology in society. There is no doubt that factor such as the pace of new discoveries and their application in biotechnology make it difficult for citizens to become well prepared in this issue because it is more and more complex to acquire an expert knowledge. In this way, beliefs and attitudes towards biotechnology can have a greater influence on the personal decisions of individuals than their explicit knowledge of the content (Anderton \& Ronald, 2017; Ruiz et al., 2021).

On the other hand, it could be said that before addressing the contents of biotechnology in the Baccalaureate, it is necessary that students possess adequate knowledge about the basic notions of genetics, cell biology and microbiology, fundamental to understand it even at the elementary level (Tsui \& Treagust, 2010). The attitudes and interests that the different applications of biotechnology arouse depends on the educational field. Thus, science students are more interested in biotechnology and this study asserted that biotechnology will be useful for students in the future. Areas of interest to students are health and food, followed by the environment and, finally, and industry.

Due to the complexity of this topic, because of the nature of its concepts, techniques and applications, as well as its social implications, the contents of biotechnology must be presented to students in an organised manner, to facilitate their learning and their relationship with the already studied material.

We consider that, at least in the Spanish context where we have carried out our research, the school curriculum should reconsider these aspects, introducing new and concrete content of interest for our students. Thus, the teaching and learning of basic concepts of genetics might be linked to current issues related to biotechnology.

Finally, we believe that it is important to take advantage of the relationship between scientific knowledge, attitudes and interests towards biotechnology, particularly in relation to applications with direct effects on health, as well as genetically modified organisms, food production, industry or environmental developments, in order to introduce classroom socio-scientific controversies that should promote the argumentation and the participation of preuniversity students in debates, analysing the information in a critical and reasoned way.

\section{ACKNOWLEDGEMENTS}

This research has been carried out within the project PGC2018-097988-A-I00 funded by: FEDER/Ministry of Science and Innovation (MCI) of Spain- State Research Agency (AEI). The authors would also like to acknowledge teachers of the different schools who participated in this research for their valuable collaboration.

\section{REFERENCES}

AbuQamar, S., Alshannag, Q., Sartawi, A., \& Iratni, R. (2015). Biotechnology Education Educational Awareness of Biotechnology Issues among Undergraduate Students at the United Arab Emirates University. Biochemistry and Molecular Biology Education, 43(4), 283-293. https:/ / doi.org/10.1002/bmb.20863

Anderton, B. N., \& Ronald, P. C. (2017). Hybrid thematic analysis reveals themes for assessing student understanding of biotechnology. Journal of Biological Education, 52(3), 271-282. https:// doi.org /10.1080/00219266.2017.1338599

Arnau Sabatés, L., \& Montané Capdevila, J. (2010). Aportaciones sobre la relación conceptual entre actitud y competencia, desde la teoría del cambio de actitudes. [Contributions on the conceptual relationship between attitude and competence, from the theory of attitude change]. Electronic Journal of Research in Educational Psychology, 8(3), 1283-1302. Retrieved from http://investigacionpsicopedagogica.org/revista/new/ContadorArtic ulo.php?465

Casanoves, M., González, Á., Salvadó, Z., Haro, J., \& Novo, M. (2015). Knowledge and Attitudes Towards Biotechnology of Elementary Education Preservice Teachers: The first Spanish experience. International Journal of Science Education, 37(17), 2923-2941. https://doi.org/10.1080/09500693. 2015.1116718

Castro, H., Serpa, F., Cavalcanti, A., Pereira, M., Paixao, I., Cisne, R., \& Delou, C. (2017). Educational 
Biotechnology: teaching and developing for the future. In The 21st World Multi-Conference on Systemics, Cybernetics and Informatics (WMSCI 2017) (pp.325-327). Retrieved from http:/ / www.iiis.org/ CDs2017/CD2017Summer/papers/SA415DR.pdf

Chen, S. Y., Chu, Y. R., Lin, C. Y., \& Chiang, T. Y. (2016). Students' knowledge of, and attitudes towards biotechnology revisited, 1995-2014: Changes in agriculture biotechnology but not in medical biotechnology. Biochemistry and Molecular Biology Education, 44(5), 475-491. https:/ / doi.org/10.1002/ bmb.20969

DaSilva, E. J. (2004). Editorial - The Colours of Biotechnology: Science, Development and Humankind. Electronic Journal of Biotechnology, 7(3). Retrieved from http:/ /hdl.handle.net/1807/5695

Dawson, V. (2007). An exploration of high school (12-17 Year Old) students' understandings of, and attitudes towards biotechnology processes. Research in Science Education, 37(1), 59-73. https: / / doi.org/10.1007/s11165-006-9016-7

De la Vega Naranjo, M., Lorca Marín, A. A., De las Heras Pérez, M. \& de los Á. (2018). Conocimientos y actitudes hacia la biotecnología en alumnos de último curso de Educación Secundaria Obligatoria [Knowledge and attitude towards biotechnology in students of the last course of Compulsory Secondary Education]. Revista Eureka sobre Enseñanza y Divulgación de las Ciencias, 15(5). https:/ / doi.org/10.25267/Rev

Díaz Martínez, V. (2010). Los colores de la biotecnología [The colors of biotechnology]. BiotechSpain, 1-4. Retrieved from https://biotechspain.com/es/ tema.cfm?iid=colores_biotecnologia.

Fonseca, M. J., Costa, P., Lencastre, L., \& Tavares, F. (2012). Multidimensional analysis of high-school students' perceptions about biotechnology. Journal of Biological Education, 46(3), 129-139. https: / / doi.org/10.1080/00219266.2011.634019

Gardner, G. E., \& Troelstrup, A. (2015). Students' Attitudes Toward Gene Technology: Deconstructing a Construct. Journal of Science Education and Technology, 24(5), 519-531. https: / / doi.org/10.1007/s10956-014-9542-4

Gaskell, G., Stares, S. Allansdottir, A., Allum, N., Corchero, C., Fischler, C., Hampel, J., Jackson, J., Kronberger, N., Mejlgaard, N., Revuelta, G., Schreiner, C., Torgensen, H. \& Wagner, W. (2006). Europeans and Biotechnology in 2005: patterns and trends. Eurobarometer 64.3. A report to the European Commission's Directorate-General for Research. Eurobarometer, 85. Retrieved from http:/ / www.cibpt.org/docs/2006-juleurobarometro-bio-2nd-ed.pdf
Hammann, M. (2018). Biotechnology. In K. Kampourakis \& M. J. Reiss (Eds.), Teaching Biology in Schools Global Research, Issues, and Trends (First edit, pp. 192-201). New York: Routledge.

Harms, U. (2002). Biotechnology education in schools. Electronic Journal of Biotechnology, 5(3), 205-211. https:/ / doi.org/10.2225/vol5-issue3-fulltext-i03

Jurkiewicz, A., Zagórski, J., Bujak, F., Lachowski, S., \& Łuszczki, M. F. (2014). Emotional attitudes of young people completing secondary schools towards genetic modification of organisms (GMO) and genetically modified foods (GMF). Annals of Agricultural and Environmental Medicine, 21(1), 205211. https:/ / pubmed.ncbi.nlm.nih.gov/24738526/

Kafarski, P. (2012). Rainbow code of biotechnology. Chemik, 66(8), 814-816. Retrieved from https:/ / www.researchgate.net/publication/28725 3802_Rainbow_code_of_biotechnology

Kidman, G. (2009). Attitudes and Interests Towards Biotechnology: The Mismatch Between Students and Teachers. Eurasia Journal of Mathematics, Science and Technology Education, 5(2), 135-143. https:/ / doi.org/10.12973/ ejmste/75265

Kidman, G. (2010). What is an "Interesting Curriculum" for biotechnology education? students and teachers opposing views. Research in Science Education, 40(3), 353-373. https://doi.org/10.1007/s11165-0099125-1

Klop, T., \& Severiens, S. (2007). An Exploration of Attitudes towards Modern Biotechnology: A study among Dutch secondary school students. International Journal of Science Education, 29(5), 663 679. https:/ / doi.org/10.1080/09500690600951556

Lieshout, E., \& Dawson, V. (2016). Knowledge of, and Attitudes Towards Health-related Biotechnology Applications Amongst Australian Year 10 High School Students. Journal of Biological Education, 50(3), 329-344. https://doi.org/10.1080/00219266. 2015.1117511

Ministry of Education, Culture and Sports (2015). Real Decreto 1105/2014 [Royal Decree 1105/2014]. BOE [State official newsletter], Sec. I (3), 169-546. Spain. Retrieved from https://www.boe.es/boe/dias/ 2015/01/03/pdfs/BOE-A-2015-37.pdf

Nordqvist, O., \& Johansson, S. (2020). Secondary School Biology Students' Attitudes towards Modern Biotechnology Characterised using Structural Equation Modeling. Eurasia Journal of Mathematics, Science and Technology Education, 16(2), e1-16. https:/ / doi.org/10.29333/ejmste/115016

Occelli, M., Vilar, M. T., \& Valeiras, N. (2011). Conocimientos y actitudes de estudiantes de la ciudad de Córdoba (Argentina) en relación a la Biotecnología. [Students' knowledge and attitudes about Biotechnology in Córdoba (Argentine)]. 
Revista Electrónica de Enseñanza de Las Ciencias, 10(2), 227-242. Retrieved from http://reec.uvigo.es/ volumenes/volumen10/ART1_VOL10_N2.pdf

Öztürk-Akar, E. (2016). Turkish university students' knowledge of biotechnology and attitudes toward biotechnological applications. Biochemistry and Molecular Biology Education, 1-11. https:/ / doi.org/ 10.1002/bmb.20996

Prokop, P., Lesková, A., Kubiatko, M., \& Diran, C. (2007). Slovakian students' knowledge of and attitudes toward biotechnology. International Journal of Science Education, 29(7), 895-907. https://doi.org/ $10.1080 / 09500690600969830$

Reid, N. (2006). Thoughts on attitude measurement. Research in Science \& Technological Education, 24(1), 3-27. https://doi.org/10.1080/02635140500485332

Ruiz González, C., Banet, E., \& López-Banet, L. (2017a). Conocimientos de estudiantes que inician el Bachillerato sobre nociones básicas de Genética y aplicaciones de la Biotecnología [Knowledge of students who begin Baccalaureate on basic notions of genetics and applications of Biotechnology]. Enseñanza de Las Ciencias, $n^{\circ}$ extraor, 1421-1428. Retrieved from https://ddd.uab.cat/record/ $184436 ? \ln =\mathrm{ca}$

Ruiz González, C., Banet, E., \& López-Banet, L. (2017b) Conocimientos de los estudiantes de secundaria sobre Herencia Biológica: implicaciones para su enseñanza [Knowledge of high school students on biological inheritance: implications for teaching]. Revista Eureka sobre Enseñanza y Divulgación de las Ciencias, 14(3), 550- 569. Retrieved from http:/ / hdl.handle.net/10498/19507

Ruiz González, C., López-Banet, L., \& Ayuso Fernández, E. (2021). Conocimientos y valoraciones de estudiantes de bachillerato sobre la utilización de aplicaciones biotecnológicas [Knowledge and assessments of bachelor's students on the use of biotechnological applications]. Revista Eureka sobre Enseñanza y Divulgación de las Ciencias, 18(1), 1102. https://doi.org/10.25267/Rev_Eureka_ensen_div ulg_cienc.2021.v18.i1.1102
Ryan, R. M., \& Deci, E. L. (2000). Intrinsic and Extrinsic Motivations: Classic Definitions and New Directions, 67, 54-67. http://doi.org/10.1006/ ceps.1999.1020

Sáez, M., Gómez-Niño, A., \& Carretero, A. (2008). Matching society values: Students' views of biotechnology. International Journal of Science Education, 30(2), 167-183. https:/ / doi.org/10.1080/ 09500690601152386

Simonneaux, L. (2000). A study of pupils' conceptions and reasoning in connection with 'microbes', as a contribution to research in biotechnology education. International Journal of Science Education, 22(6), 619-644. https://doi.org/10.1080/ 095006900289705

Tsui, C. \& Treagust, D. (2010). Evaluating Secondary Students' Scientific Reasoning in Genetics Using a Two-Tier Diagnostic Instrument. International Journal of Science Education, 32 (8), 1073-1098. https:// doi.org/10.1080/09500690902951429

UNESCO United Nations Educational Scientific and Cultural Organization (UNESCO) (2017). Biotechnology. Retrieved from http://www.unesco.org/new/en/naturalsciences/science-technology/basic-sciences/lifesciences/biotechnology/

Usak, M., Erdogan, M., Prokop, P., \& Ozel, M. (2009). High school and university students' knowledge and attitudes regarding biotechnology. Biochemistry and Molecular Biology Education, 37(2), 123-130. https:/ / doi.org/10.1002/bmb.20267

Vázquez, A., \& Manassero, M.A., (2007). En defensa de las actitudes y emociones en la educación científica (I): evidencias y argumentos generales [In defense of attitudes and emotions in scientific education (I): evidence and general arguments]. Revista Eureka de Enseñanza y Divulgación de Ciencias, 4(2), 247-271. https:/ / doi.org/10.25267/Rev_Eureka_ensen_div ulg_cienc.2007.v4.i2.03

\section{http://www.ejmste.com}

